\title{
Alteromonas addita sp. nov.
}

Correspondence

Elena P. Ivanova

eivanova@swin.edu.au
Elena P. Ivanova, ${ }^{1,2}$ John P. Bowman, ${ }^{3}$ Anatoly M. Lysenko, ${ }^{4}$
Natalia V. Zhukova, ${ }^{5}$ Nataliya M. Gorshkova, ${ }^{2}$ Alexander F. Sergeev ${ }^{6}$
and Valery V. Mikhailov ${ }^{2}$

${ }^{1}$ Swinburne University of Technology, PO Box 218, Hawthorn, Victoria 3122, Australia

${ }^{2}$ Pacific Institute of Bioorganic Chemistry of the Far-Eastern Branch of the Russian Academy of Sciences, 690022 Vladivostok, Pr. 100 Let Vladivostoku 159, Russian Federation

${ }^{3}$ School of Agricultural Science, University of Tasmania, Private Bag 54, Hobart, Tasmania 7001, Australia

${ }^{4}$ S. N. Winogradsky Institute of Microbiology of the Russian Academy of Sciences, 117312 Moscow, Russian Federation

${ }^{5}$ Institute of Marine Biology of the Far-Eastern Branch of the Russian Academy of Sciences, 690041, Vladivostok, Russian Federation

${ }^{6}$ V. I. Il'ichev Pacific Oceanological Institute of the Far-Eastern Branch of the Russian Academy of Sciences, Baltiiskaya Str. 43, 690017, Vladivostok, Russian Federation

On the basis of phenotypic, genotypic characteristics and analysis of $16 \mathrm{~S}$ rRNA gene sequences, a novel species belonging to the genus Alteromonas is described. A non-pigmented, motile, Gram-negative bacterium designated R10SW $13^{\top}$ was isolated from sea water samples collected in Chazhma Bay (Sea of Japan, Pacific Ocean). The novel organism mainly grew between $4{ }^{\circ} \mathrm{C}$ and $37{ }^{\circ} \mathrm{C}$, was neutrophilic and slightly halophilic, tolerating up to $10 \% \mathrm{NaCl}$. Strain R10SW $13^{\top}$ was haemolytic and was able to degrade starch and Tween 80 and to degrade gelatin and agar weakly, but did not degrade casein. Phosphatidylethanolamine $(44 \cdot 3 \pm 0.9 \%)$ and phosphatidylglycerol $(55 \cdot 7 \pm 0 \cdot 9 \%)$ were the predominant phospholipids. The major fatty acids formed were typical for the genus Alteromonas, including $16: 0,16: 1 \omega-7$ and $18: 1 \omega-7$. The $\mathrm{G}+\mathrm{C}$ content of the DNA was $43.4 \mathrm{~mol} \%$. DNA-DNA hybridization experiments showed 38-53\% binding with the DNAs of type strains of phylogenetically related species of the genus Alteromonas, namely: Alteromonas macleodii, Alteromonas marina, Alteromonas stellipolaris, Alteromonas litorea, 'Alteromonas macleodii subsp. fijiensis' and 'Alteromonas infernus'.

Based on these results, a novel species, Alteromonas addita sp. nov., is proposed, with strain

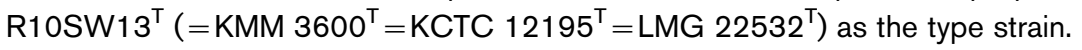

Volume 1 of the first edition of Bergey's Manual of Systematic Bacteriology described only one genus of Gram-negative, aerobic, heterotrophic, marine bacteria with a single polar flagellum, Alteromonas Baumann et al. 1972 (Baumann et al., 1984; Baumann \& Baumann, 1981). During its dynamic and turbulent taxonomic history, the genus has undergone detailed investigations (Van Landschoot \& De Ley, 1983; Gauthier et al., 1995; Van Trappen et al., 2004; Ivanova et al., 2004b) and currently comprises the species Alteromonas

Abbreviation: FAME, fatty acid methyl ester.

The GenBank/EMBL/DDBJ accession number for the $16 \mathrm{~S}$ rRNA gene sequence of Alteromonas addita R10SW13 ${ }^{\top}$ is AY682202.

DNA $\mathrm{G}+\mathrm{C}$ contents and DNA-DNA relatedness values for Alteromonas species including $A$. addita are available as supplementary material in IJSEM Online. macleodii Baumann et al. 1972, A. marina Yoon et al. 2003, A. stellipolaris Van Trappen et al. 2004 and A. litorea Yoon et al. 2004.

In this study we report on the characterization of a novel bacterium of the genus Alteromonas, strain R10SW13 ${ }^{\mathrm{T}}$, isolated from sea water samples collected in Chazhma Bay (Gulf of Peter the Great, Sea of Japan, Pacific Ocean). This work was part of a taxonomic survey of free-living microbial populations of the bay in the north-west Pacific Ocean, sediments of which were contaminated by radionuclides. Water samples were collected during October-November 2000 from two different horizons, from the first metre below the surface and from 1-2 $\mathrm{m}$ from the bottom (a varying depth of 9-13 m) (salinity, $32 \%$; temperature, $13 \cdot 6^{\circ} \mathrm{C}$ ), using a standard hydrological plastic bathometer. Samples were kept at $4{ }^{\circ} \mathrm{C}$ and processed within $4-8 \mathrm{~h}$. A portion of 
sea water $(0 \cdot 1 \mathrm{ml})$ was plated onto marine agar 2216 (Difco) or medium B which contained $0 \cdot 2 \%(\mathrm{w} / \mathrm{v})$ Bacto peptone (Difco), $0 \cdot 2 \%(\mathrm{w} / \mathrm{v})$ casein hydrolysate (Merck), $0 \cdot 2 \%$ $(\mathrm{w} / \mathrm{v})$ Bacto yeast extract (Difco), $0 \cdot 1 \%(\mathrm{w} / \mathrm{v})$ glucose, $0.02 \%(\mathrm{w} / \mathrm{v}) \mathrm{KH}_{2} \mathrm{PO}_{4}, 0 \cdot 005 \%(\mathrm{w} / \mathrm{v}) \mathrm{MgSO}_{4} .7 \mathrm{H}_{2} \mathrm{O}, 1 \cdot 5 \%$ $(\mathrm{w} / \mathrm{v})$ Bacto agar (Difco), $50 \%(\mathrm{v} / \mathrm{v})$ natural sea water and $50 \%(\mathrm{v} / \mathrm{v})$ distilled water at $\mathrm{pH} 7 \cdot 8$. Plates were incubated aerobically at room temperature (approx. $22-25^{\circ} \mathrm{C}$ ) and growth was monitored after 5, 7 and 10 days. The isolation and purification procedure has been described elsewhere (Ivanova et al., 1996). Strains were stored at $-80{ }^{\circ} \mathrm{C}$ in marine broth 2216 (Difco) supplemented with $20 \%$ (v/v) glycerol.

The following physiological and biochemical properties were examined by methods described by Smibert \& Krieg (1994) unless indicated: oxidation/fermentation of glucose, denitrification (Azegami et al., 1987), oxidase and catalase activity, gelatin liquefaction, arginine dihydrolase, lysine decarboxylase, ornithine decarboxylase, sodium requirement $[0,0 \cdot 5,1,3,6,8,10,12 \%(\mathrm{w} / \mathrm{v}) \mathrm{NaCl}]$, indole and $\mathrm{H}_{2} \mathrm{~S}$ production and the ability to hydrolyse starch, Tween 80 and casein. Growth at different temperatures was determined in marine broth 2216 (Difco) and on plates with medium B after $24-72$ h at $2,4,6,29,30,35$ and $37^{\circ} \mathrm{C}$. The Biolog GN test kit was also used to examine the primary oxidation of 95 carbon compounds as described elsewhere (Ivanova et al., 1998). Antibacterial activity was assessed by the agar diffusion assay, based on the method described by Barry (1980). Haemolysis was tested on blood-agar plates ( $6.5 \%$ sheep blood; Merck).

Phenotypic analysis showed that the novel organism had all the characteristics of Alteromonas-like bacteria: it was Gram-negative, strictly aerobic, oxidase- and catalasepositive, did not produce $\mathrm{H}_{2} \mathrm{~S}$ or indole and was negative for denitrification. The novel isolate did not show antibacterial activity, but possessed haemolytic activity. The morphological and physiological properties examined are also shown in Table 1 and given in the species description.

For analysis of phospholipids and fatty acids, the strains were grown at $28^{\circ} \mathrm{C}$ on marine agar 2216 . After 48 h growth, cells were harvested. The lipids were extracted by a modified method of Bligh \& Dyer (1959). Polar lipids were separated by two-dimensional micro-thin-layer chromatography in solvent systems described by Vaskovsky \& Terekhova (1979). Lipids were detected on the TLC using a $10 \%$ solution of $\mathrm{H}_{2} \mathrm{SO}_{4}$ in methanol with subsequent heating to $180^{\circ} \mathrm{C}$ and by using specific reagents for phospholipids (see Vaskovsky et al., 1975), amino-containing lipids (2\% ninhydrin in acetone) and choline lipids (Dragendorfs reagent). Phospholipids were quantified by the method of Vaskovsky et al. (1975).The lipids were treated with $5 \%$ $\mathrm{HCl}$ in methanol at $80^{\circ} \mathrm{C}$ for 180 min to produce fatty acid methyl esters (FAMEs) (Christie, 1982). FAMEs were analysed by FID-GC (Shimadzu GC-17) with a fused silica capillary column $(30 \mathrm{~m} \times 0 \cdot 25 \mathrm{~mm})$, coated with Supelcowax 10 at $210^{\circ} \mathrm{C}$. Helium was used as the carrier gas. FAMEs
Table 1. Characteristics that differentiate Alteromonas addita sp. nov. from phylogenetically related Alteromonas species

Species: 1, A. addita sp. nov.; 2, A. macleodii; 3, A. marina; 4, A. stellipolaris; 5, A. litorea. All species/strains are Gram-negative, motile, oxidase- and catalase-positive and negative for indole and $\mathrm{H}_{2} \mathrm{~S}$ production, grow at $3-6 \% \mathrm{NaCl}$ and produce lipase (Tween 80). +, Positive; -, negative; W, weak reaction; V, variable; ND, no data. Data were obtained in this study and from Yoon et al. (2003, 2004) and Van Trappen et al. (2004).

\begin{tabular}{|lccccc|}
\hline Characteristic & $\mathbf{1}$ & $\mathbf{2}^{*}$ & $\mathbf{3}$ & $\mathbf{4}$ & $\mathbf{5}$ \\
\hline Production of pigments & - & - & - & + & - \\
Growth at: & & & & & \\
$\quad 4{ }^{\circ} \mathrm{C}$ & + & - & + & + & - \\
$40{ }^{\circ} \mathrm{C}$ & - & + & + & - & + \\
Nitrate reduction to nitrite & - & $\mathrm{V}(-)$ & - & - & $\mathrm{ND}$ \\
Growth in NaCl at: & & & & & \\
$10 \%$ & + & - & + & + & + \\
$15 \%$ & - & - & + & - & - \\
Hydrolysis of: & & & & & \\
$\quad$ Gelatin & $\mathrm{W}$ & $\mathrm{V}(+)$ & + & + & + \\
Agar & $\mathrm{W}$ & - & - & - & - \\
$\quad$ Starch & + & $\mathrm{V}(+)$ & + & + & + \\
Haemolysis & + & - & $\mathrm{ND}$ & - & $\mathrm{ND}$ \\
Assimilation of: & & & & & \\
$\quad$ D-Mannitol & - & $\mathrm{V}(+)$ & - & + & - \\
L-Lactate & + & $\mathrm{V}(+)$ & - & - & - \\
G + C content (mol\%) & 43 & $45-46$ & $44-45$ & 45 & 46 \\
\hline
\end{tabular}

${ }^{\star}$ Data in parentheses reported by Yoon et al. (2003).

were identified by comparing the retention times with those of authentic standards and using equivalent chain length measurements. To ensure correct identification, FAMEs were analysed by GC-MS using a model GCMSQP5050A (Shimadzu) fitted with an MDN-5S capillary column $(30 \mathrm{~m} \times 0.25 \mathrm{~mm})$. The column temperature was programmed for $1 \mathrm{~min}$ hold at $170{ }^{\circ} \mathrm{C}$, followed by an increase to $240{ }^{\circ} \mathrm{C}$ at $2{ }^{\circ} \mathrm{C} \mathrm{min}{ }^{-1}$ and a hold at $240{ }^{\circ} \mathrm{C}$ for $20 \mathrm{~min}$. The temperature of the injector and detector were $250{ }^{\circ} \mathrm{C}$. Phosphatidylethanolamine $(44 \cdot 3 \pm 0 \cdot 9 \%)$ and phosphatidylglycerol $(55 \cdot 7 \pm 0 \cdot 9 \%)$ were the major constituents of the phospholipids. Traces of bisphosphatidic acid, lysophosphatidylethanolamine and phosphatidic acid were also detected. Neither diphosphatidyl glycerol nor glycophospholipids were found, which is in agreement with our previous observations (Ivanova et al., 2000). The fatty acids formed by the novel organism were (\%): $12: 0(1 \cdot 0)$; $13: 0(0.5)$; iso- $14: 0(0.5) ; 14: 0(2 \cdot 9) ; 14: 1(1 \cdot 9) ; 15: 0$ $(1 \cdot 8) ; 15: 1 \omega-8(2 \cdot 7)$; iso- $16: 0(0 \cdot 4) ; 16: 0(15 \cdot 2) ; 16: 1 \omega-7$ $(30 \cdot 1) ; 17: 0(2 \cdot 0) ; 17: 1 \omega-8(4 \cdot 1)$; iso- $18: 0(7 \cdot 8) ; 18: 0$ $(1 \cdot 0) ; 18: 1 \omega-7(11 \cdot 7) ; 10: 03-\mathrm{OH}(3 \cdot 3)$; iso- $11: 03-\mathrm{OH}$ $(2 \cdot 2) ; 11: 03-\mathrm{OH}(2 \cdot 5)$; iso-12:0 $3-\mathrm{OH}(1 \cdot 1) ; 12: 03-\mathrm{OH}$ $(1 \cdot 9) ; 14: 03-\mathrm{OH}(2 \cdot 9) ; 15: 03-\mathrm{OH}(1 \cdot 2)$ and $16: 03-\mathrm{OH}$ $(1 \cdot 4)$. 
The small-subunit rRNA genes were sequenced as described elsewhere (Ivanova et al., 2004a). The 16S rRNA gene sequence of R10SW $13^{\mathrm{T}}$ was aligned and compared to the GenBank nucleotide database using an online BLAST search. Analyses of $16 \mathrm{~S}$ rRNA gene sequences were done using PHYLIP version 3.57c (Felsenstein, 1993). DNADIST was used to determine sequence similarities using the maximum-likelihood algorithm option. Phylogenetic trees were constructed with the neighbour-joining method by using the program NEIGHBOR. The outgroup on the Alteromonas trees was Escherichia coli. Analysis of the $16 \mathrm{~S}$ rRNA gene sequences revealed that the novel isolate belongs to the genus Alteromonas, forming a coherent cluster (bootstrap value of $100 \%$ ) with all other recognized species of the genus Alteromonas (Fig. 1). Strain R10SW $13^{\mathrm{T}}$ shared $97 \% 16 \mathrm{~S}$ rRNA gene sequence similarity with $A$. macleodii, A. marina, A. litorea, 'Alteromonas infernus' and $99 \%$ similarity with A. stellipolaris. This level of similarity supports the phylogenetic inclusion of strain R10SW $13^{\mathrm{T}}$ in the genus Alteromonas.

DNA was isolated from strain $\mathrm{R} 10 \mathrm{SW} 13^{\mathrm{T}}$ following the method of Marmur (1961) and the G+C content of the DNA was determined using the thermal denaturation method of Marmur \& Doty (1962) as $43 \cdot 4 \mathrm{~mol} \%$. DNADNA hybridization was performed spectrophotometrically as described by De Ley et al. (1970). Type strains were obtained from the American Type Culture Collection and the BCCM/LMG Bacteria Collection or were kindly provided by Dr J.-H. Yoon and Dr G. Barbier. DNA from strain R10SW $13^{\mathrm{T}}$ showed $38-53 \%$ binding with the DNA of type strains of Alteromonas species with validly published names and some other strains, e.g. 'A. macleodii subsp. fijiensis' and 'A. infernus' (detailed results available as supplementary

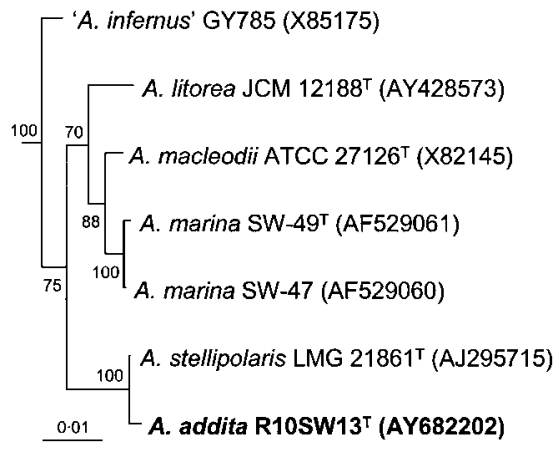

Fig. 1. Phylogenetic position of Alteromonas addita sp. nov. and related Alteromonas species according to $16 \mathrm{~S}$ rRNA gene sequence analysis. The topology shown was obtained using the bioNJ algorithm and 1000 bootstrap replications with Kimura's two-parameter correction for the distances. Percentages of bootstrap are indicated only for branches that were also retrieved by maximum-parsimony and maximum-likelihood $(P<0.01)$; these branches should be considered as the only robust clusters identified by this analysis. Bar, 0.01 substitutions per nucleotide position. material in IJSEM Online). These values are far lower than $70 \%$, which is the cut-off value recommended for definition of a genomic species (Wayne et al., 1987), and clearly indicate that strain $\mathrm{R} 10 \mathrm{SW} 13^{\mathrm{T}}$ represents a genomic species that is separate from recognized Alteromonas species. Further, the novel isolate can be readily distinguished from other Alteromonas species by the combination of phenotypic, genotypic and phylogenetic features, e.g. range of salinity and temperature for growth, presence of haemolytic activity and the ability to hydrolyse agar (Table 1). While R10SW $13^{\mathrm{T}}$ had patterns of phospholipids and cellular fatty acids that were characteristic of the genus, the large proportion of $16: 1 \omega-7$ is an additional species-specific feature. Thus, the results obtained in this study provide evidence that R10SW $13^{\mathrm{T}}$ represents a novel species of the genus Alteromonas for which we propose the name Alteromonas addita sp. nov.

\section{Description of Alteromonas addita sp. nov.}

Alteromonas addita (ad.di'ta. L. fem. part. adj. addita added, joined to the genus).

Gram-negative, rod-shaped, single cells, about $0 \cdot 7-0 \cdot 9 \mu \mathrm{m}$ in diameter. Motile, with a single polar flagellum. Aerobic. Chemoorganotroph with respiratory metabolism. Colonies are uniformly round, $2-3 \mathrm{~mm}$ in diameter, regular, convex and smooth on marine agar or B medium. Does not form endospores. Does not accumulate poly- $\beta$-hydroxybutyrate as an intracellular reserve product. Requires $\mathrm{Na}^{+}$ions or sea water for growth; growth occurs in media with $1-10 \%$ $\mathrm{NaCl}$. Temperature for growth ranges from 4 to $37^{\circ} \mathrm{C}$; no growth is detected at $40^{\circ} \mathrm{C}$. The $\mathrm{pH}$ for growth ranges from $6 \cdot 0$ to $10 \cdot 0$, with optimum at $7 \cdot 5-8 \cdot 0$. Negative for arginine dihydrolase, lysine decarboxylase and ornithine decarboxylase. Weakly decomposes gelatin and agar. Other physiological properties are listed in Table 1. Utilizes the following carbon sources: dextrin, glycogen, Tween-80, Nacetyl-D-glucosamine, adonitol, D-cellobiose, L-arabinose, D-arabitol, i-erythritol, D-fructose, L-fucose, $m$-inositol, $\alpha$-D-lactose, lactulose, maltose, D-mannose, D-melibiose, methyl $\beta$-D-glucoside, D-psicose, D-raffinose, L-rhamnose, D-sorbitol, sucrose, D-trehalose, turanose, xylitol, acetic acid, cis-aconitic acid, formic acid, D-galactonic acid lactone, D-galacturonic acid, D-glucosaminic acid, Dglucuronic acid, $\alpha$-hydroxybutyric acid, $\beta$-hydroxybutyric acid, $\gamma$-hydroxybutyric acid, $p$-hydroxyphenylacetic acid, itaconic acid, $\alpha$-ketoglutaric acid, $\alpha$-ketobutyric acid, $\alpha$ ketovaleric acid, DL-lactic acid, malonic acid and propionic acid. Phosphatidylethanolamine $(44 \cdot 3 \pm 0 \cdot 9 \%)$ and phosphatidylglycerol $(55 \cdot 7 \pm 0 \cdot 9 \%)$ are the predominant phospholipids. The main cellular fatty acids are $16: 1 \omega-7,16: 0$, $18: 1 \omega-7$ and iso- $18: 0$ (approx. $65 \%$ ). The $\mathrm{G}+\mathrm{C}$ content of the DNA of the type strain is $43 \mathrm{~mol} \%$.

The type strain is strain R10SW $13^{\mathrm{T}}\left(=\mathrm{KMM} 3600^{\mathrm{T}}=\right.$ KCTC $12195^{\mathrm{T}}=$ LMG $22532^{\mathrm{T}}$ ), isolated from sea water from Chazhma Bay in the Sea of Japan, Pacific Ocean. 


\section{Acknowledgements}

This study was partially supported by funds from the Australian Research Council (ARC), grant \# 2-2.16 from the Federal Agency for Science of the Ministry of Education and Science of the Russian Federation, grant 02-04-48211 from the Russian Foundation for Basic Research and grant 'Molecular and Cell Biology' from the Presidium of the Russian Academy of Sciences.

\section{References}

Azegami, K., Nishiyama, K., Watanabe, Y., Kadota, I., Ohuchi, A. \& Fukazawa, C. (1987). Pseudomonas plantarii sp. nov., the causal agent of rice seedling blight. Int J Syst Bacteriol 37, 144-152.

Barry, A. I. (1980). Procedures and theoretical considerations for testing antimicrobial agents in agar media. In Antibiotics in Laboratory Medicine, pp. 10-16. Edited by V. Logan. Baltimore, MD: William \& Wilkins.

Baumann, P. \& Baumann, L. (1981). The marine Gram-negative eubacteria; genera Photobacterium, Beneckea, Alteromonas, Pseudomonas, and Alcaligenes. In the Prokaryotes. A Handbook on Habitats, Isolation, and Identification of Bacteria, pp. 1302-1330. Edited by M. P. Starr, H. Stolp, H. G. Trüper, A. Balows \& H. G. Schlegel. Berlin: Springer.

Baumann, L., Baumann, P., Mandel, M. \& Allen, R. D. (1972). Taxonomy of aerobic marine eubacteria. J Bacteriol 110, 402-429.

Baumann, P., Gauthier, M. J. \& Baumann, L. (1984). Genus Alteromonas Baumann, Baumann, Mandel and Allen 1972, $418^{\mathrm{AL}}$. In Bergey's Manual of Systematic Bacteriology, vol. 1, pp. 343-352. Edited by N. R. Krieg \& J. G. Holt. Baltimore: Williams \& Wilkins. Bligh, E. G. \& Dyer, W. J. (1959). A rapid method of lipid extraction and purification. Can J Biochem Physiol 37, 911-915.

Christie, W. W. (1982). Lipid Analysis: Isolation, Separation, Identification and Structural Analysis of Lipids, 2nd edn. Oxford: Pergamon Press.

De Ley, J., Cattoir, H. \& Reynaerts, A. (1970). The quantitative measurement of DNA hybridization from renaturation rates. Eur J Biochem 12, 133-142.

Felsenstein, J. (1993). PHYLIP (phylogeny inference package), version 3.5c. Department of Genetics, University of Washington, Seattle, USA.

Gauthier, G., Gauthier, M. \& Christen, R. (1995). Phylogenetic analysis of the genera Alteromonas, Shewanella, and Moritella using genes coding for small-subunit rRNA sequences and division of the genus Alteromonas into two genera, Alteromonas (emended) and Pseudoalteromonas gen. nov., and twelve new species combinations. Int J Syst Bacteriol 45, 755-761.

Ivanova, E. P., Kiprianova, E. A., Mikhailov, V. V., Levanova, F. G., Garagulya, A. G., Gorshkova, N. M., Yumoto, N. \& Yoshikawa, S. (1996). Characterization and identification of marine Alteromonas nigrifaciens strains and emendation of the description. Int $J$ Syst Bacteriol 46, 223-228.
Ivanova, E. P., Kiprianova, E. A., Mikhailov, V. V. \& 8 other authors (1998). Phenotypic diversity of Pseudoalteromonas citrea from different marine habitats and emendation of the description. Int J Syst Bacteriol 48, 247-256.

Ivanova, E. P., Zhukova, N. V., Svetashev, V. I., Gorshkova, N. M., Kurilenko, V. V., Frolova, G. M. \& Mikhailov, V. V. (2000). Evaluation of phospholipid and fatty acid compositions as chemotaxonomic markers of Alteromonas-like proteobacteria. Curr Microbiol 41, 341-345.

Ivanova, E. P., Gorshkova, N. M., Sawabe, T. \& 8 other authors (2004a). Sulfitobacter delicatus sp. nov. and Sulfitobacter dubius sp. nov., respectively from a starfish (Stellaster equestris) and sea grass (Zostera marina). Int J Syst Evol Microbiol 54, 475-480.

Ivanova, E. P., Flavier, S. \& Christen, R. (2004b). Phylogenetic relationships among marine Alteromonas-like proteobacteria: emended description of the family Alteromonadaceae and proposal of Pseudoalteromonadaceae fam. nov., Colwelliaceae fam. nov., Shewanellaceae fam. nov., Moritellaceae fam. nov., Ferrimonadaceae fam. nov., Idiomarinaceae fam. nov. and Psychromonadaceae fam. nov. Int J Syst Evol Microbiol 54, 1773-1788.

Marmur, J. (1961). A procedure for the isolation of deoxyribonucleic acid from microorganisms. J Mol Biol 3, 208-218.

Marmur, J. \& Doty, P. (1962). Determination of the base composition of deoxyribonucleic acid from its thermal denaturation temperature. J Mol Biol 5, 109-118.

Smibert, R. M. \& Krieg, N. R. (1994). Phenotypic characterization. In Methods for General and Molecular Bacteriology, pp. 607-654. Edited by P. Gerhardt, R. G. E. Murray, W. A. Wood \& N. R. Krieg. Washington, DC: American Society for Microbiology.

Van Landschoot, A. \& De Ley, J. (1983). Intra- and intergeneric similarities of the rRNA cistrons of Alteromonas, Marinomonas (gen. nov.) and some other Gram-negative bacteria. J Gen Microbiol 129, 3057-3074.

Van Trappen, S., Tan, T.-L., Yang, J., Mergaert, J. \& Swings, J. (2004). Alteromonas stellipolaris sp. nov., a novel, budding, prosthecate bacterium from Antarctic seas, and emended description of the genus Alteromonas. Int J Syst Evol Microbiol 54, 1157-1163.

Vaskovsky, V. E. \& Terekhova, T. A. (1979). HPTLC of phospholipid mixtures containing phosphatidylglycerol. J High Resolut Chromatogr Chromatogr Commun 2, 671-672.

Vaskovsky, V. E., Kostetsky, E. Y. \& Vasendin, I. M. (1975). A universal reagent for phospholipid analysis. J Chromatogr 114, 129-141.

Wayne, L. G., Brenner, D. J., Colwell, R. R. \& 9 other authors (1987). Report of the ad hoc committee on reconciliation of approaches to bacterial systematics. Int J Syst Bacteriol 37, 463-464.

Yoon, J.-H., Kim, I.-G., Kang, K. H., Oh, T.-K. \& Park, Y.-H. (2003). Alteromonas marina sp. nov., isolated from seawater of the East Sea in Korea. Int J Syst Evol Microbiol 53, 1625-1630.

Yoon, J.-H., Yeo, S.-H., Oh, T.-K. \& Park, Y.-H. (2004). Alteromonas litorea sp. nov., a slightly halophilic bacterium isolated from an intertidal sediment of the Yellow Sea in Korea. Int J Syst Evol Microbiol 54, 1197-1201. 